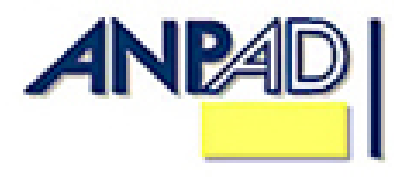

Available online at http://www.anpad.org.br/bar

BAR, Rio de Janeiro, v. 10, n. 2, art. 3, pp. 158-175, Apr./June 2013

$(\mathrm{coc}) \mathrm{Er}$

\title{
The Enhancing Impact of Friendship Networks on Sales Managers' Performance
}

\author{
Danny Pimentel Claro \\ E-mail address: danny@insper.edu.br \\ Insper Instituto de Ensino e Pesquisa \\ Insper, Rua Quatá, 300, São Paulo, SP, 04546-042, Brazil. \\ Silvio Abrahão Laban Neto \\ E-mail address: silvioaln@insper.edu.br \\ Insper Instituto de Ensino e Pesquisa \\ Insper, Rua Quatá, 300, São Paulo, SP, 04546-042, Brazil. \\ Priscila Borin de Oliveira Claro \\ E-mail address: priscila.claro@insper.edu.br \\ Insper Instituto de Ensino e Pesquisa \\ Insper, Rua Quatá, 300, São Paulo, SP, 04546-042, Brazil.
}

Received 26 January 2012; received in revised form 2 October 2012 (this paper has been with the authors for two revisions); accepted 11 October 2012; published online $1^{\text {st }}$ April 2013. 


\begin{abstract}
This paper examines how relationships with friends moderate the impact of professional networks on sales performance. Based on a sample of 204 sales managers in a professional service company, this study presents evidence that friendship networks amplify the effect of sales forces' professional networks on new product sales as well as on prospecting and converting new deals. Our results offer important insights into the socio-cognitive perspective of sales management literature and suggest that firms should encourage managers to improve their friendships in order to access valuable information that will enhance customer knowledge and support their sales efforts.
\end{abstract}

Key words: networks; sales; relationship marketing. 


\section{Introduction}

Marketing scholars have increasingly recognized the need for salespeople to possess sophisticated knowledge about their firm's capabilities and competitive advantages in order to identify opportunities and approaches for creating customer value (Weitz \& Bradford, 1999). As customer problems become more complex and heterogeneous, salespeople must also be able to coordinate the efforts of individuals needed to effectively serve customers and manage relationships (Moon \& Armstrong, 1994). Relationship marketing research has paid attention to external or inter-firm networks (e.g. alliance partners, supply networks), but recent work reveals that internal or intra-firm networks are critical to performance (Bradford et al., 2010; Steward, Walker, Hutt, \& Kumar, 2010). The salesperson's ability to access more and better sales resources from coworkers has been shown to have a direct impact on sales performance (Plouffe \& Barclay, 2007). More specifically, research suggests that salespeople's ability to leverage their firm's relational information processes, in order to gain and subsequently pass on information about their firm's expertise and competencies to their customers, has a significant impact on the value derived by both the buyer and the seller (Jayachandran, Sharma, Kaufman, \& Raman, 2005; Palmatier et al., 2006). Consequently, sales researchers have identified the need for more studies on the activities salespeople engage in to form intra-organizational relationships (e.g. via social networks) in order to gain access to useful resources possessed by other people in their firm (Steward et al., 2010; Workman, Homburg, \& Jensen, 2003).

A network is the social capital created within a firm, resulting in a salesperson's web of interpersonal ties that are used to secure resources for the purpose of providing value and managing customer relationships (Coleman, 1990). Salespeople then become flow creators who are known as real sources of ideas, which enhance their status and peers' desire to cooperate (Flaherty, Lam, Lee, Mulki, \& Dixon, 2012). Salespeople draw on the contributions of diverse intra-firm network members in order to: (a) understand their firm's capabilities and what it can do for their customers; and (b) encourage exchanges with individuals who can provide the resources needed to craft customer solutions (Jones et al., 2005; Weitz \& Bradford, 1999). Research demonstrates that access to members in a dense network, especially through close ties, positively affects sales manager's performance (Moran, 2005).

While providing valuable insights into sales management, recent trends in theory and practice highlight an important gap in the socio-cognitive sales paradigm. No studies, to our knowledge, have examined the purpose of sales manager friendship networks. Literature has stressed the importance of identifying the purpose of forming a network (Cross \& Prusak, 2002; Krackhardt, 1988). In this paper, we consider two types of network: friendship and professional. The friendship network refers to a free set of relationships of affective and social bonds. The professional network addresses who goes to whom for work-related or technical advice. More recently, marketing scholars have proposed that in order to create effective solutions for customers, salespeople must build intra-firm sales networks that are both sparse and dense (Üstüner \& Godes, 2006). This reinforces the need to address the sales network more deeply.

The goal of our paper is to investigate how relationships with friends moderate the impact of professional networks on a set of sales performance indicators. We developed three hypotheses to study the issue of networks and a sales manager's performance. Empirical data was collected from 204 sales managers in a professional service firm. We mapped the sales managers' networks: their friendship network contained 928 ties and their professional network 1,642 ties. Additional profile and sales related information was also drawn to provide control variables for the model.

The concept of network type will be explored in the following section. We shall take up the friendship and advice purposes of networks and then examine the network concept as it refers to the number of ties a sales person maintains. In the third section, we discuss sales performance indicators and then develop our hypotheses based on existing network and sales force literature. The 
methodology is presented in the fifth section and is followed by the results. At the end, we present a discussion of these results and our conclusions.

\section{Sales Networks: Professional and Friendship Ties}

Research shows that access to heterogeneous knowledge can enhance a salesperson's creativity in finding a customer solution as well as the salesperson's own performance (Rodan \& Galunic 2004). For example, research implies that salespeople working within a group or network of intra-firm members are most effective when the group members represent and provide unique knowledge (Cummings, 2004). Effective salespeople adaptively coordinate intra-firm expertise to execute their firms' relationship marketing strategies and achieve financial performance (Steward et al., 2010; Üstüner \& Godes, 2006). It has been proposed that integration and information sharing across vastly different functions leads sales teams to discover new ways to satisfy customer needs (Jones et al., 2005). Studies have highlighted the need to coordinate and facilitate the flow of resources between intra-firm members (Flaherty et al., 2012; Steward et al., 2010). Given the need to have access to diverse intra-firm information and expertise, a key concern is how salespeople can best motivate others to share what they know with them. Research shows that ties with intra-firm members that are both professionally and friendship based facilitate greater information sharing among individuals (Beckman \& Haunschild, 2002). Marketing scholars have long recognized the importance of business and friendship roles for inter-firm relationships (Heide \& Wathne, 2006; Price \& Arnold, 1999), but others have proposed that friendships in a network of intra-organizational ties can influence a range of business outcomes, such as information sharing (Grayson, 2007).

Built on Coleman's (1988) discussion of social capital, Burt (1992) defines this capital by its function. According to these two highly regarded authors, social capital is not a single entity but a variety of different entities having two characteristics in common: they all consist of some aspect of social structure, and they facilitate certain actions by individuals who are within the structure. Like other forms of capital, social capital is productive, making certain goals possible which would not be attainable in its absence. It consists of a social structure formed by people or corporate actors. Unlike other forms of capital, social capital is inherent to the structure of the relationships between and among actors.

In sociological terms, each actor has control over certain resources (i.e. information) and interests in certain resources and events, and social capital constitutes a particular kind of resource available to an actor. The concept of social capital allows for the taking of information and shows the way that different pieces of information can be combined with other resources to produce different system-level behavior or, in other cases, different outcomes for individuals.

Information is essential in any business setting and provides the basis for action in a social structure. Information can be expected to be spread across the various people in a market, but it will circulate within groups before it circulates between groups. However, the acquisition of information is costly. At a minimum, it requires attention which is always in scarce supply. One means by which information can be acquired is by the use of social relationships that are maintained for different purposes.

Network relationships may be assessed as a multidimensional concept. One critical issue is which network relationships enable a sales manager to increase net sales? A network composed of incidental communication links, such as a mechanical How do you do? may not be as rich in relevant information as a network composed of critical advice relationships. When you meet someone at an event, it is not surprising to find that you have a mutual friend in common. In the literature, the term small world is often associated with the tendency for people in different geographic locations to be connected through only a few intermediaries. Granovetter (1973) showed that weak ties are actually a question of the number of intermediaries. Watts (2004) and Barabasi (2003) showed how close 
someone is to the point where that person is lead back to his or her own ego-network. More recently, Swaminathan and Moorman (2009) showed that several unique network characteristics can produce a fruitful environment for cooperation.

Cognitive social structure considers two different primary types of networks. First is the advice network which represents the instrumental, workflow-based network in an organization (Krackhardt, 1990). Basically, it addresses who goes to whom for work-related or technical advice (Cross \& Prusak, 2002). Second is the friendship network. This is a free set network. It is not necessarily linked to the routine work done in the organization, but it does capture important affective and social bonds that can affect trust, especially in times of change (Krackhardt \& Stern, 1988).

\section{Hypotheses}

For this study, we developed three hypotheses about sales managers' social networks and sales performances as depicted in Figure 1.

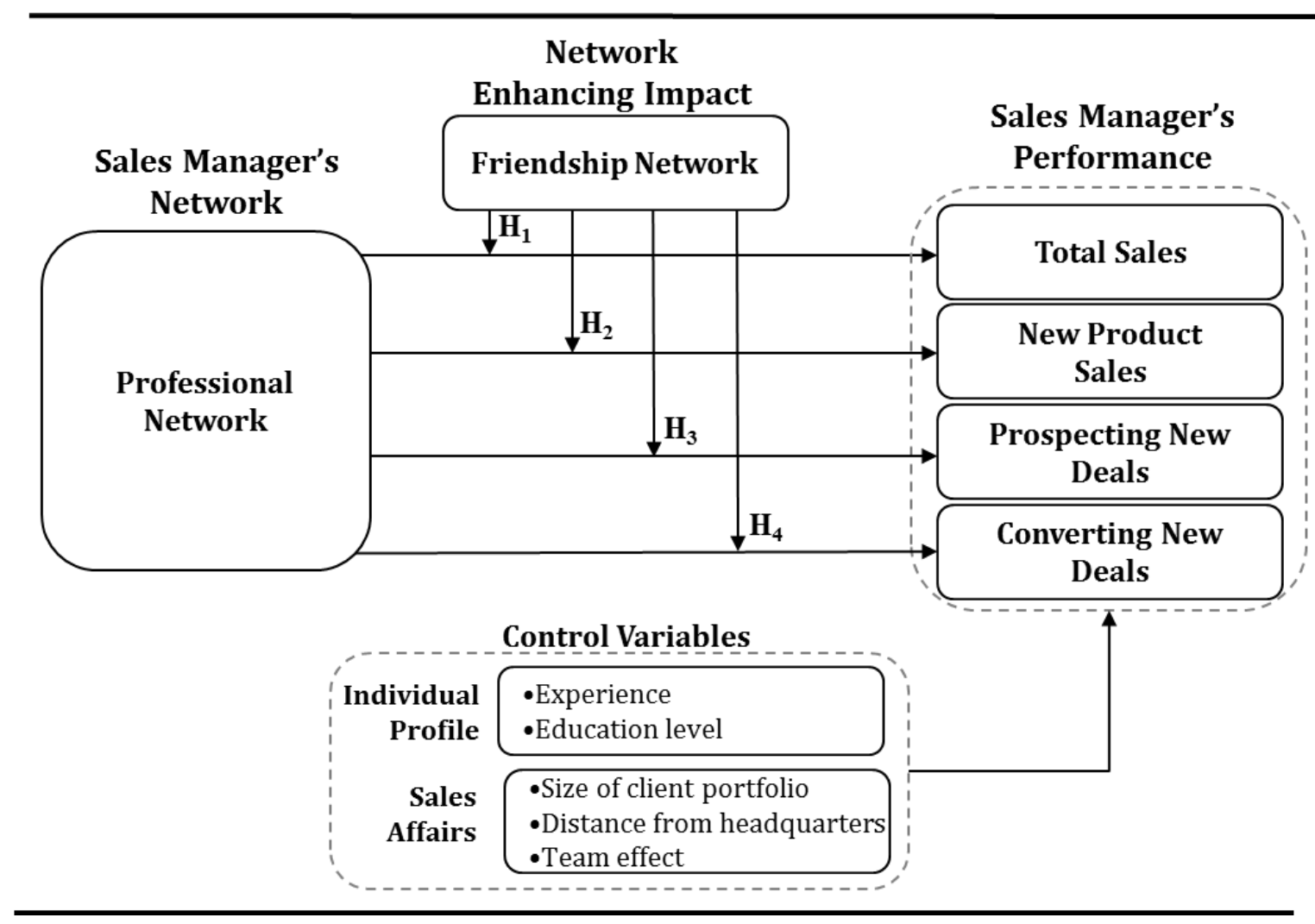

Figure 1. Moderating Effect of Friendship Networks on the Impact of Professional Networks on Sales Performance.

Scholars have long argued that single-purpose relationships are less advantageous than multipurpose relationships (Stern, 1979). People in different kinds of relationships that salespeople maintain in an intra-firm sales network are motivated to exchange resources for different reasons (Adler \& Kwon, 2002). The enhancing impact of friends may be assessed as the tendency for two or more networks to foster sales performance (Van Den Bulte, \& Wuyts, 2007). The professional relationship acts as a donor of knowledge based on instrumental motivations such as career advancement, cost reduction, or competitive rivalry (Adler \& Kwon, 2002). The friendship tie, while not necessarily linked to routine activities related to the sales work, does capture important affective and social bonds that can drive trust (Brass, 1984). Friendship exchanges are sources of shared identities (e.g. 
organizational) and social support, forged by consummatory motivations, or socialization based normative frameworks that guide collective action and bind communities (Podolny \& Baron, 1997).

Extant research suggests that a friends' network may have an impact on a professional network because ties with friends represent robust relationships, based on trust, that are more conducive to knowledge transfer (Beckman \& Haunschild, 2002), and positively influence resource exchange and cooperation within the sales network (Lazega \& Pattison, 1999). Sales managers maintain friendly ties that are more stable than professional ones (e.g. work), by making exit more costly, as losing a business associate may also result in the loss of a friend (Seevers, Skinner, \& Kelley, 2007). Friends contribute to the total relational strength between salespeople and their professional contacts, by imparting more opportunities to request support, provide support, and build positive valence (Van Den Bulte \& Wuyts, 2007). Recent research suggests that cooperation across independent functional units represents a key challenge for salespeople striving to improve the solutions they develop and deliver to customers (Tuli, Bharadwaj, \& Kohli, 2010). Moreover, the moderating impact of friends increases the number of ways that a favor can be reciprocated between salespeople and others in their network. Professional advice, for example, can be repaid with a dinner, lunch or an invitation to a social event. In addition, friends' ties can provide the salesperson with a stronger voice within their firm, via relationship commitments, resulting in their business interests being more highly prioritized by network members (Aguilera \& Jackson, 2003). Ties that go beyond arm's-length relations and evolve into close friendships have been shown to be critical to a firm's market performance and long-term survival (Uzzi, 1997).

Taking the rationale provided above, we expect that ties with friends will moderate the impact of professional networks on sales performance. By connecting with friends, sales managers can get information about sales leads, client demands, the development of new products, and tools to operationalize solutions more informally - i.e. rapidly and reliably - that may amplify the effect of professional networks on total sales. Therefore:

H1: Friend networks amplify the effect of professional networks on total sales.

New product sales are complex by nature. Companies develop new products by listening to customer needs and their own personnel and R\&D. Sales managers may be trained to offer products that may require specific techniques and sales pitches. Friends may introduce some personnel that can help provide the skills necessary for selling these new products. Friends work as a lubricant for professional networks. Therefore:

H2: Friend networks amplify the effect of professional networks on new product sales.

In the sales process there are two critical stages: the identification of prospects and the conversion of new deals (Üstüner \& Godes, 2006). The identification of prospects for new deals depends on a salesperson's acquiring precise and timely information about opportunities - preferably ones about which the competitors have no idea. Friends in this context may enhance a professional network's impact by allowing for contacts with others outside the sales territory or within other departments of the company. Therefore:

H3: Friend networks amplify the effect that professional networks have on identifying new deals.

In the deal conversion stage, the salesperson has to come up with a solution for the prospect's demand, but a salesperson rarely provides this without help. Success depends on the manager's ability to activate his professional network by means of friends who are trusted people and quick responses from others within his own organization. Friends tend to be more open to relating experiences about how opportunities were identified and were converted into sales. Through trusting relationships with friends, a sales manager can use these experiences to activate a professional network to explore opportunities and convert them into sales; even for clients from different industries. Friends can help mobilize and coordinate these professional ties. Therefore: 
H4: Friend networks amplify the effect that professional networks have on converting new deals into sales.

In addition to the hypotheses related to the network of a salesperson, we can intuitively expect that other factors may impact sales performance. The experience of a sales manager might influence his/her performance positively. One might suggest that with aging a manager gains experience and becomes better prepared for the challenges of selling. The education level is also expected to have a positive impact on performance. Sales managers are required to engage in before and after sales activities. Most of the activities are related to complex technical methods related to the products. Size of client portfolio can also impact performance via the potential opportunities a sales person may explore. Sales managers that have a large number of clients can learn from other clients and engage in a virtual cycle where clients may positively recommend the salesperson to other clients in the portfolio. Another factor that one might consider is the effect distance from headquarters may play on a salesperson's performance. One might suggest that salespeople physically close to the more highly ranked executives of the firm's formal hierarchy (e.g. president, vice presidents and directors) will perform better. Finally, we considered team effect. As salespeople may be geographically close to peers within one division, they are physically separated from the rest of the large sales' group. One might suggest that a salesperson's performance is influenced by the division performance and the economic prosperity of the area that the salesperson belongs to. We do not develop specific hypotheses for each of these factors, though they are included in the model estimation. Before presenting the analysis and results of the hypotheses test, we describe the method used in this study.

\section{Method}

Data was collected from 204 sales managers from a professional service company. The focal company is the Brazilian branch of a British multinational in the IT and Market Intelligence sectors whose primary product is a credit evaluation tool. As the leader in its industry, this company has reached over a half billion dollars in sales and has about 150 thousand direct clients and 400 thousand indirect clients who belong to several industries (e.g. perishable consumer goods retailers, electronics retailers, and industrial firms). The company is an interesting empirical object because of its vast number of salespeople and the complexities of its sales which require tailor-made solutions and customer service.

In the professional service business, information is critical. Sales managers are always consulted for technical advice. They visit clients in order to identify specific needs and bundle an array of products for the whole cycle of client demands. This firm has 60 offices with independent operations spread all over the country.

Four measures of performance were used. The measure of individual total sales was computed (US\$) on the basis of the financial records for the years 2008/09. New product sales were computed in (US\$) on the basis of sales and financial records for the same period. The identification of prospects is accounted for by the dollars registered by sales managers in the company's operational system. Finally, the conversion of new deals is computed on the basis of the dollar sales from successes in relation to prospect identification. Prospects and conversions are computed for the years 2008/09.

The network measures are based on a name generating questionnaire for two types of networks, namely professional and friendship. The name generating questions used for this study were adapted from Burt (1992) and Podolny and Baron (1997). To identify the sales manager professional network, the following questions were asked: Whom did you go to for any professional help or advice over the last month? Whom do you talk to when you miss a work-related meeting? Who are the people that could replace you in case of your promotion? To identify the sales manager friendship network, the 
following question was asked: With whom would you discuss personal matters (e.g. family matters, confidential issues)?

Each of the 310 sales managers received an email with a login and password to access an electronic questionnaire. Three follow-ups were emailed every 7 days. To ensure high quality responses, all directors and regional managers were personally informed of the importance of the research. The senior Human Resources (HR) Executive and the research team were in charge of follow-ups. Of the 310 targeted sales people in the firm, 297 were available. The others included 6 on leave and 7 on medical leave. After a twenty-five day data collection effort, the survey produced a response rate of $69 \%$, yielding 204 completed questionnaires.

All names were entered in UCINET 6 to draw the network and estimate the degree centrality metric. Each name generated in the questionnaire was coded and entered as a 2 by 2 matrix of contacts. To estimate degree centrality, we followed the procedure used by Borgatti, Everett and Freeman (2002) considering the number of direct contacts to a given point in the network (i.e. number of persons) in a symmetric graph. This allows us to estimate the number of ties received by a given point in the network and the number of ties initiated by that given point. The degrees (in and out) then consist of the sums of the values of the ties. This estimate is normalized by dividing by the maximum possible degree and expressing this as a percentage. There is a measure for the professional network and another measure for the friend network.

We included five control variables. The measure for experience represents the number of years that the respondent has been involved with sales or commercial activities in the company. We also included a variable to control for the manager's education level, considering the number of years of schooling that the sales manager has completed. This is a categorical variable ranging from no formal schooling (0) to a graduate degree (8). Size of client portfolio is a direct count of the number of clients for which each sales manager is responsible. Distance is the total number of miles that separate the sales manager from the firm's headquarters. The measure for team effect is the individual's net sales minus the total sales of the office to which he or she belongs. The correlation matrix and descriptive statistics are shown in Table 1. The correlations between the measures do not suggest problems of pairwise collinearity that would preclude the use of all constructs in the estimation. 
Table 1

\section{Descriptive Statistics and Correlations}

\begin{tabular}{|c|c|c|c|c|c|c|c|c|c|c|c|c|c|}
\hline \multirow{2}{*}{ Variable } & \multirow{2}{*}{ Mean } & \multirow{2}{*}{$\begin{array}{l}\text { Standard } \\
\text { Deviation }\end{array}$} & \multicolumn{11}{|c|}{ Correlation Matrix } \\
\hline & & & 1. & 2. & 3. & & 4. & 5. & 6. & 7. & 8. & 9. & 10. \\
\hline 1. Total Sales (m) & 4.46 & 7.83 & 1.00 & & & & & & & & & & \\
\hline 2. New Products (m) & 0.12 & 0.33 & $.71 * *$ & 1.00 & & & & & & & & & \\
\hline 3. New Prospects (m) & 8.44 & 18.76 & $.82 * *$ & $.60 * *$ & 1.00 & & & & & & & & \\
\hline 4. New Deals (m) & 0.41 & 0.97 & .01 & -.03 & .04 & & 1.00 & & & & & & \\
\hline $\begin{array}{l}\text { 5. Professional } \\
\text { Network }\end{array}$ & 1.23 & 0.68 & $.41 * *$ & $.35^{* *}$ & $.34 * *$ & & .02 & 1.00 & & & & & \\
\hline 6. Friend Network & 0.72 & 0.28 & $.26^{* *}$ & $.24 * *$ & $.21 * *$ & & .07 & $.47 * *$ & 1.00 & & & & \\
\hline 7. Experience (years) & 6.05 & 4.97 & $.39 * *$ & $.34 * *$ & $.31 * *$ & - & .08 & $.36^{* *}$ & $.22 * *$ & 1.00 & & & \\
\hline 8. Education level & 3.55 & 0.95 & $.41^{* *}$ & $.41 * *$ & $.37 * *$ & - & .12 & $.31 * *$ & $.20 * *$ & $.23^{* *}$ & 1.00 & & \\
\hline $\begin{array}{l}\text { 9. Size of Client } \\
\text { Portfolio }\end{array}$ & 82.12 & 145.33 & $.28 * *$ & $.23^{* *}$ & $.25^{* *}$ & & .01 & $.26 * *$ & .07 & $.36^{* *}$ & $.20 * *$ & 1.00 & \\
\hline 10. Distance (miles) & 410.60 & 593.21 & $-.20 * *$ & $-.21 * *$ & -.07 & & .11 & $-.22 * *$ & $-.28 * *$ & $.15^{*}$ & -.11 & $.39 * *$ & 1.00 \\
\hline 11. Team Effect (m) & 69.34 & 182.43 & $.55^{* *}$ & $.51 * *$ & $.43 * *$ & - & .08 & $.53 * *$ & $.31 * *$ & $.27 * *$ & $.35^{* *}$ & $.17 *$ & $-.40 * *$ \\
\hline
\end{tabular}

Note: $(\mathrm{m})$ : million

$* \mathrm{p}<.05, * * \mathrm{p}<.01$ 


\section{Results}

We mapped the sales managers' networks: their friend network contains 928 ties and the professional network 1,642 ties. Figure 2 shows the network diagram of the sales force's professional and friend networks. The professional network has a centralized shape with high ranking sales managers and directors in the center. The friend network has an interesting sparse design with an island of ties. This isolated group of individuals is composed of sales people with short tenures and a new office territory.
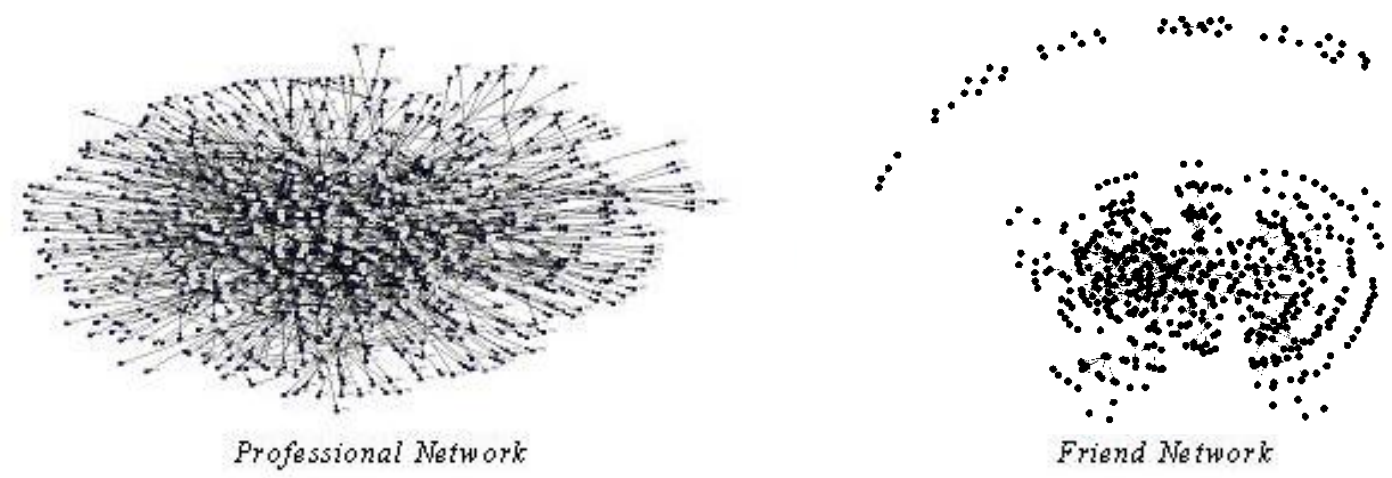

Figure 2. Sociogram of Professional and Friend Networks.

Table 2 summarizes the results of a series of ordinary least square regression analysis. The central hypotheses of this study focus on the moderating impact of friendship networks. In statistical terms, a moderator is "a variable that affects the direction and/or strength of the relation between a predictor variable and a dependent variable" (Baron \& Kenny, 1996, p. 1174). Following the procedure in Aiken and West (1991), we multiplied the original variables and mean-centered all of the estimated variables, except the dependent one. This procedure prevents the multiplicative variable from presenting high multicollinearity with other predictors in the model. VIF tests and tolerance indices were checked and are below the threshold values suggested by Aiken and West (1991).

Three models for each equation were estimated by first entering the control variables (model 1), then entering the main variables (model 2) and finally the moderating variable (model 3). Standardized coefficients of the estimated regression model are presented as well as the t-value coefficient. The standardized coefficient allows for a comparison of coefficient size because all measures are in the same metric, namely, standardized normal deviates. The full models (models 3 ) of each equation were statistically significant below the 0.01 level in the F-test. The adjusted $\mathrm{R}^{2}$ values for the significant equations are above 0.222 , which indicates that the results of the estimated equations present a robust explanatory power. Also, the $\mathrm{R}^{2}$ Change shows a significant increase in the explanatory power by entering the interaction variable. The explanatory power of the equations supports the examination of individual coefficients and the testing of the effects of each individual variable. 
Table 2

\section{Results of the Ordinary Least Square Regression}

\begin{tabular}{|c|c|c|c|c|c|c|c|c|c|c|c|c|}
\hline \multirow[t]{2}{*}{ Variable } & \multicolumn{3}{|c|}{ Total Sales } & \multicolumn{3}{|c|}{ New Product Sales } & \multicolumn{3}{|c|}{ Prospecting New Deals } & \multicolumn{3}{|c|}{ Converting New Deals } \\
\hline & Model 1 & Model 2 & Model 3 & Model 1 & Model 2 & Model 3 & Model 1 & Model 2 & Model 3 & Model 1 & Model 2 & Model 3 \\
\hline \multicolumn{13}{|l|}{ Network Enhancing Factor } \\
\hline \multirow[t]{2}{*}{$\begin{array}{l}\text { Professional Network * Friend } \\
\text { Network } \mathrm{H}_{1,2,3,4}\end{array}$} & & & .567 & & & .485 & & & .428 & & & .448 \\
\hline & & & $(2.83)^{* *}$ & & & $(2.35)^{* *}$ & & & $(1.94)^{*}$ & & & $(1.97)^{*}$ \\
\hline \multicolumn{13}{|l|}{ Network Variables } \\
\hline \multirow[t]{2}{*}{ Professional Network } & & .020 & .291 & & .026 & .291 & & .043 & .191 & & .009 & .253 \\
\hline & & $(.25)$ & $(2.22)$ & & $(.34)$ & $(2.15)^{*}$ & & $(.53)$ & $(1.32)$ & & $(.11)$ & $(1.69) \dagger$ \\
\hline \multirow[t]{2}{*}{ Friend Network } & & .120 & .181 & & .025 & .233 & & .027 & .200 & & .175 & .061 \\
\hline & & $(1.87) \dagger$ & $(1.46)$ & & $(.37)$ & $(1.82) \dagger$ & & $(.39)$ & $(1.46)$ & & $(2.41)^{*}$ & (.43) \\
\hline \multicolumn{13}{|l|}{ Control Variables } \\
\hline \multirow[t]{2}{*}{ Experience (years) } & .225 & .199 & .184 & .186 & .187 & .174 & .142 & .127 & .116 & .150 & .119 & .107 \\
\hline & $(3.26)^{* *}$ & $(3.10)^{* *}$ & $(2.91)^{* *}$ & $(2.94)^{* *}$ & $(2.84)^{* *}$ & $(2.67)^{* *}$ & $(2.01)^{*}$ & $(1.82) \dagger$ & $(1.66) \dagger$ & $(2.12)^{*}$ & $(1.64)$ & $(1.48)$ \\
\hline \multirow[t]{2}{*}{ Education level } & .106 & .096 & .107 & .216 & .217 & .226 & .216 & .210 & .219 & .121 & .110 & .118 \\
\hline & $(1.74) \dagger$ & $(1.57)$ & $(1.78) \dagger$ & $(3.52) * *$ & $(3.49)^{* *}$ & $(3.67)^{* *}$ & $(3.29)^{* * *}$ & $(3.17)^{* *}$ & $(3.32) * *$ & $(1.76) \dagger$ & $(1.60)$ & $(1.74) \dagger$ \\
\hline \multirow[t]{2}{*}{ Size of Client Portfolio } & .147 & .133 & .100 & .123 & .125 & .097 & .096 & .087 & .062 & .036 & .022 & .004 \\
\hline & $(2.17)^{*}$ & $(1.95)^{*}$ & $(1.47)^{*}$ & $(1.78) \dagger$ & $(1.78) \dagger$ & $(1.37)$ & $(1.32)$ & $(1.16)$ & (.83) & $(.47)$ & $(.28)$ & $(-.05)$ \\
\hline \multirow[t]{2}{*}{$\begin{array}{l}\text { Distance from headquarters } \\
\text { (miles) }\end{array}$} & -.061 & -.022 & -.028 & -.140 & -.137 & -.142 & .015 & .030 & .026 & -.040 & .009 & .005 \\
\hline & $(-.85)$ & $(-.30)$ & $(-.38)$ & $(-1.93) \dagger$ & $(-1.82) \dagger$ & $(-1.90) \dagger$ & $(.19)$ & $(.37)$ & $(.32)$ & $(-.50)$ & $(.12)$ & $(.06)$ \\
\hline \multirow[t]{2}{*}{ Team Effect (US\$) } & .391 & .372 & .345 & .309 & .315 & .292 & .310 & .392 & .272 & .311 & .296 & .275 \\
\hline & $(5.57)^{* *}$ & $(5.05)^{* * *}$ & $(4.73)^{* *}$ & $(4.38)^{* *}$ & $(4.18)^{* *}$ & $(3.88)^{* *}$ & $(4.08)^{* *}$ & $(3.64) * *$ & $(3.38)^{* *}$ & $(3.92)^{* *}$ & $(3.57)^{* *}$ & $(3.31)^{* *}$ \\
\hline
\end{tabular}

Continues 


\section{Table 2 (continued)}

\begin{tabular}{|c|c|c|c|c|c|c|c|c|c|c|c|c|}
\hline \multirow[t]{2}{*}{ Variable } & \multicolumn{3}{|c|}{ Total Sales } & \multicolumn{3}{|c|}{ New Product Sales } & \multicolumn{3}{|c|}{ Prospecting New Deals } & \multicolumn{3}{|c|}{ Converting New Deals } \\
\hline & Model 1 & Model 2 & Model 3 & Model 1 & Model 2 & Model 3 & Model 1 & Model 2 & Model 3 & Model 1 & Model 2 & Model 3 \\
\hline $\mathrm{R}^{2}$ & 0.386 & 0.399 & 0.423 & 0.368 & 0.368 & 0.386 & 0.282 & 0.284 & 0.298 & 0.213 & 0.238 & 0.253 \\
\hline Adjusted $\mathrm{R}^{2}$ & 0.370 & 0.377 & 0.399 & 0.352 & 0.346 & 0.360 & 0.264 & 0.258 & 0.269 & 0.193 & 0.211 & 0.222 \\
\hline $\mathrm{R}^{2}$ Change & & 0.013 & $0.024 * *$ & & 0.095 & $5.517 * *$ & & 0.002 & 3,759* & & $0.025^{*}$ & $0.015^{*}$ \\
\hline F-statistic & $24.85 * *$ & $18.58 * *$ & $17.84 * *$ & $23.01 * *$ & $16.32 * *$ & $15.29 * *$ & $15.53 * *$ & $11,11 * *$ & $10.32 * *$ & $8.23 * *$ & $8.23 * *$ & $8.23 * *$ \\
\hline
\end{tabular}

Note. The table reports standardized coefficients with $\mathrm{t}$-values in parentheses.

$\dagger \mathrm{p}<.10 ;{ }^{*} \mathrm{p}<.05 ;{ }^{* *} \mathrm{p}<.01$. 
Our results show overall support for the moderating impact of friendship networks on the effect of professional networks on the four indicators of sales managers' performance. We find significant support for our hypotheses. Sales manager's friends moderately amplify the effect of the professional network on total sales $(\beta=.327, \mathrm{p}<.10)$ according to hypothesis 1 . Friend networks also significantly amplify the effect of professional networks on new product sales $(\beta=.485, \mathrm{p}<.01)$, the identification of prospects $(\beta=.428, \mathrm{p}<.05)$ and the conversion of new deals $(\beta=.448, \mathrm{p}<.05)$ as hypothesized (in $\mathrm{H} 2$ and $\mathrm{H} 3$ respectively). For prospecting and converting new deals, our findings provide evidence for the theoretical discussion of the existing literature (Üstüner \& Goddes, 2006). Maintaining a professional network in combination with a friendship network appears to have a consistent effect on performance, especially when compared to the isolated impact of such networks on performance measures. Sales managers who exclusively use one or the other do not enhance performance, except for a marginal effect on new product sales. This result reinforces the importance of leveraging professional networks together with friendship networks to achieve higher performance.

We elaborated a descriptive matrix to further investigate the moderating impact of friendship networks. Table 3 displays the average dollar figure for each of the performance indicators and crosses it with a high and low level of the two networks. The results provide additional evidence that salespeople who combine high levels of professional network and friendship network achieve higher performance across all different indicators. For instance, a salesperson with high professional network and high friendship network levels can make on average 2.8 times more total sales than a peer with low professional and friendship network levels. When comparing the networks, it is better for the salesperson to maintain the professional rather than the friendship network. For instance, the total sales average of a salesperson with high friend and low professional network levels is $48 \%$ larger than another salesperson with high professional and low friend network levels. Therefore, a salesperson achieves high performance when a friendship network is combined with a professional one.

Table 3

\section{Performance (US\$) and Networks}

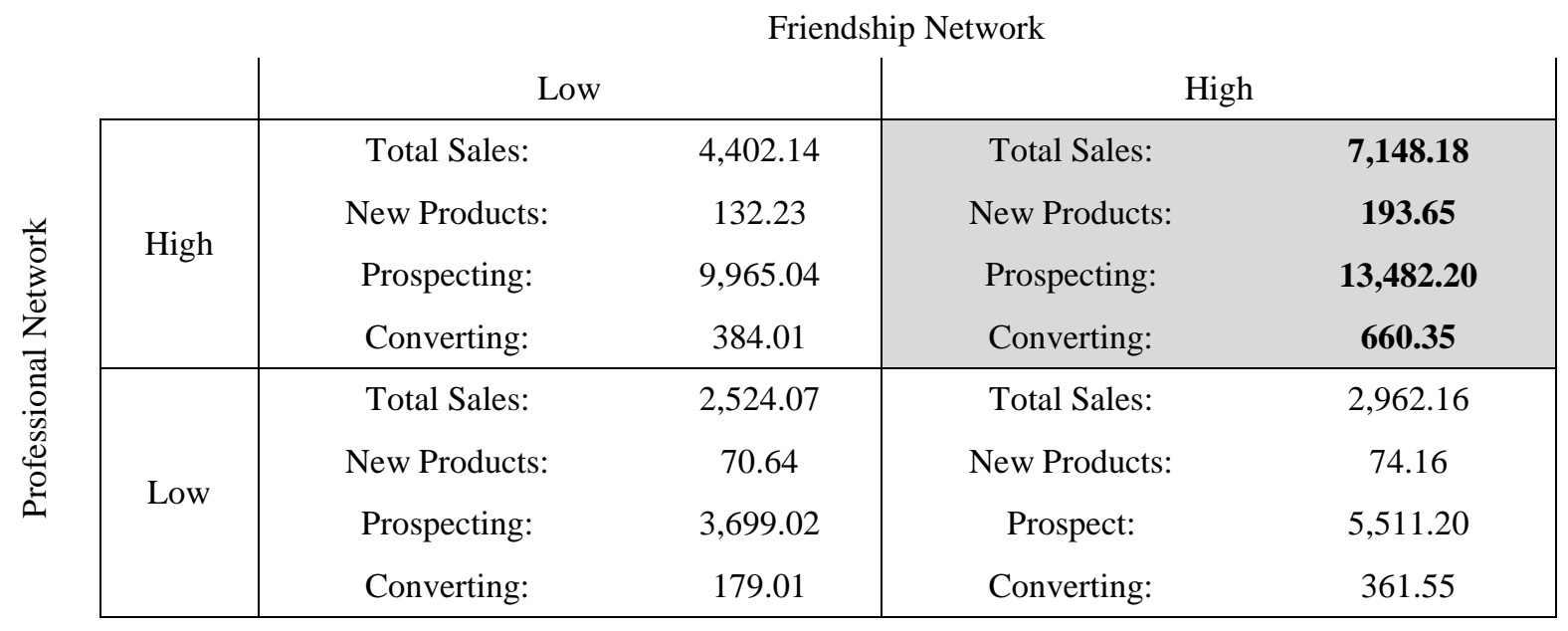

Several control variables have a significant effect on sales manager performance. Experience influences the volume of total sales $(\beta=.205, \mathrm{p}<.01)$ and new product sales $(\beta=.174, \mathrm{p}<.01)$. Experience has a marginal effect on new prospects $(\beta=.116, \mathrm{p}<.10)$ and no impact on the conversion of new deals. One explanation for this result is that experienced sales managers are acknowledged in the portfolio of day-to-day products and new products, but appear to have difficulty in using their network in prospecting and converting new deals. Another speculation is that, as prospecting and converting new deals may encompass new products, experienced sales managers may have a stable and saturated client portfolio. These experienced managers must sell new products to oversupplied clients in order to increase total sales and keep up with the annual sales target. Education presents a similar pattern. The 
higher the sales manager's education level, the better the sales indicators. One might suggest that constant training and study is necessary for sales managers. As the sales process requires a great deal of skills and capabilities, sales managers sell products and prospect new sales. However, education and experience do not appear to have an effect on the conversion of new deals. As expected, the size of the client portfolio influences the value of total sales $(\beta=.134, \mathrm{p}<.05)$. Sales managers can have large values for dollar sales, but this leverages neither new product sales nor the prospecting for and conversion of new deals. Distance negatively influences new product sales $\beta=-.142, p<.05$ ) and marginally influences total sales $(\beta=-.128, p<.10)$. We can speculate that sales managers are assisted by headquarters personnel in their sales activities. The managers who are located closer to headquarters may perform better in selling new products because they are close to sources of information (e.g. P\&D) and high ranked personnel, resources that may be leveraged and required in new product introductions. Finally, a sales manager's office team appears to have a consistent and significantly positive impact on all sales performance indicators. This result corroborates the impact networks have because the performance of a team close to a sales manager is relevant to his or her sales performance.

\section{Concluding Remarks}

Our study aims to investigate the enhancing impact friendship networks have on the effect of professional networks and subsequently on a set of sales performance indicators. While past studies in marketing have examined the direct effects of knowledge structure characteristics (Sujan, Sujan, \& Bettman, 1988; Szymanski \& Churchill, 1990) on performance, our findings offer insights into the socio-cognitive perspective of sales management literature. In general terms, social network literature has put forward the idea that the better a sales manager's network, the better the outcome. This is associated with the information benefits one might expect in terms of the control of information or being the first one to access information. People who do well are somehow better connected. The perspective we take in this paper follows the metaphor in which the social structure defines a kind of capital that can create advantages for groups or individuals in pursuing their goals (Flaherty et al., 2012; Steward et al., 2010). Our study shows that sales managers enhance performance by embeddedness, as suggested in Granovetter's classical study (1985). The friend network allows for sales managers to rely on social norms and the trust of friendship.

The current study adds to sales manager literature by identifying the role of intra-firm social capital for improving sales performance. By combining sales management theory with social network theory, this study sheds light on the ways in which managers acquire the information and cooperation from intra-organizational members that they need to effectively serve customers (Bradford et al., 2010). The study focuses on the impact of two predominant network types: professional and friendship. In addition, we identify important individual and sales profile factors that influence sales performance. This study is interesting in that it uses network data to test hypotheses that predict a sales manager's access to information and the cooperative support embedded in an intra-firm network.

\section{Managerial Implications and Future Research}

Considering the results of our study and the discussion provided in the hypotheses presentation, it appears to be important for sales managers to have accurate understanding of their network. Without this, any evaluation of the costs and benefits of alternative responses to customers based on the information obtained from the network could be misguided. More specifically, if managers either over or underestimate the potential positive impact of information obtained from their close knit group of friend contacts, their sales effort response cannot be properly set up. Firms can foster manager initiatives toward improving relationships with other sales managers and staff personnel that may 
enhance sales managers' friendship networks. This will allow them to access valuable information to support their sales efforts. The mere process of gathering information from known ties and developing new ties of information may substantially enhance the chances of sales success.

Our study's implications are best viewed within the context of a practice oriented approach in regard to the trend towards increasing customer knowledge and sales performance. Almost without exception, such an approach tends to view customer relationships as a universally desirable idea - this is because some customers are not as profitable as others. We advise managers to complement this approach with our hypotheses and results. It is worth noting that the basic postulate of our work is that a sales manager may increase customer knowledge by setting up relationships with others. In the professional service settings where we tested our hypotheses sales managers looked for new ways to satisfy customers. In this particular situation, there are enough advantages for sales managers to organize themselves to set up close friendship and professional network structures. In the absence of competitive advantages, social networks do not have beneficial effects and, given the costs associated with maintaining the contacts within the network, it is likely to be detrimental to performance. At the very least, our study should serve as a cautionary tale about the conditions that create the need for crafting network relationships. The value of a relationship is not defined inside the relationship; it is defined by the social context around that relationship (Burt, 2005).

In a future study, the relationship within a network may be investigated in terms of its structure and tie strength. The strong and weak tie literature (Granovetter, 1973; Lin, 1988) presents interesting findings in the context of a sales force. Future research must consider other concepts studied in social capital literature. For instance, network diversity may cause an impact on sales performance. Network diversity has been studied as the wide variety of contacts a sales manager may have: be they commercial within a department or with other departments (e.g. administrative, financial, IT, and logistics). Our study focused on the professional service industry, which requires a great deal of customization and customer solutions. Future studies may address other industries and contexts to test the potential mediating or moderating impact of friendship networks.

We model social capital as a positive driver of sales manager performance. While this is the approach taken by most research, scholars recognize that social capital development can come with risks (Adler \& Kwon, 2002). Future research should identify the dark side of social capital effects on sales manager performance. For example, managers whose networks are well developed could manipulate information exchanges in a negative fashion as their contacts may be unable to monitor all exchanges. In addition, identifying the impact of social capital on relational information processes (Jayachandran et al., 2005) and customer solution processes (Tuli et al., 2010) could be a fruitful stream of research. Finally, future research may address the hierarchy of contacts, be they friendly or professional ties. Maintaining contacts with top executives can help managers foresee future movements of the company (e.g. investments, territory expansion, overall strategy), which helps managers in defining priorities and efforts. These well-positioned sales managers may be the first ones to know. In our research, this impact is implicitly considered. Future research may address this issue explicitly.

\section{References}

Adler, P. S., \& Kwon, S. (2002). Social capital: prospects for a new concept. Academy of Management Review, 27(1), 17-40. doi: 10.2307/4134367

Aguilera, R., \& Jackson, G. (2003). The cross-national diversity of corporate governance: dimensions and determinants. The Academy of Management Review, 28(3), 447-465. doi: 10.5465/AMR.2003.10196772 
Aiken, L. S., \& West, S. G. (1991). Multiple regression: testing and interpreting interactions. Newbury Park: Sage.

Barabasi, A. L. (2003). Linked: how everything is connected to everything else and what it means. Plume: New York.

Baron, R. M., \& Kenny, D. A. (1986). The moderator-mediator variable distinction in social psychological research: conceptual, strategic, and statistical considerations. Journal of Personality and Social Psychology, 51(6), 1173-1182. doi: 10.1037/0022-3514.51.6.1173

Beckman, C., \& Haunschild, P. R. (2002). Network learning: the effects of partners' heterogeneity of experience on corporate acquisitions. Administrative Science Quarterly, 47(1), 92-124. doi: $10.2307 / 3094892$

Borgatti, S. P., Everett, M. G., \& Freeman, L. C (2002). UCINET for Windows. Harvard: Analytic Technologies.

Bradford, K., Brown, S., Ganesan, S., Hunter, G., Onyemah, V., Palmatier, R., Rouziès, D., Spiro, R., Sujan, H., \& Weitz, B. (2010). The embedded sales force: connecting buying and selling organizations. Marketing Letters, 21(3), 239-253. doi: 10.1007/s11002-010-9106-1

Brass, D. (1984). Being in the right place: a structural analysis of individual influence in an organization. Administrative Science Quarterly, 29(4), 518-539. doi: 10.1109/TEM.2007.906859

Burt, R. S. (1992). Structural holes: the social structure of competition. Cambridge: Harvard University Press.

Burt, R. S. (2005). Brokerage and closure: an introduction to social capital. Oxford, New York: Oxford University Press.

Coleman, J. S. (1988). Social capital in the creation of human capital. American Journal of Sociology, 94(s1), S95-S120. doi: 10.1086/228943

Coleman, J. S. (1990). Foundations of social theory. Cambridge, MA: Harvard University Press.

Cross, R., \& Prusak, L. (2002). The people who make organizations go or stop. Harvard Business Review, 80(6), 104-112.

Cummings, J. (2004). Work groups, structural diversity, and knowledge sharing in a global organization. Management Science, 50(3), 352-364. doi: 10.1287/mnsc.1030.0134

Flaherty, K., Lam, S. K., Lee, N., Mulki, J. P., \& Dixon, A. L. (2012). Social network theory and the sales manager role: engineering the right relationship flows. Journal of Personal Selling and Sales Management, 32(1), 29-40. doi: 10.2753/PSS0885-3134320104

Granovetter, M. S. (1973). The strength of weak ties. American Journal of Sociology, 78(6), 13601380. doi: $10.1086 / 225469$

Granovetter, M. S. (1985). Economic action and social structure: the problem of embeddedness. American Journal of Sociology, 91(3), 481-510. doi: 10.1086/228311

Grayson, K. (2007). Friendship versus business in marketing relationships. Journal of Marketing, 71(4), 121-139. doi: 10.1509/jmkg.71.4.121

Heide, J., \& Wathne, K. (2006). Friends, businesspeople, and relationship roles: a conceptual framework and a research agenda. Journal of Marketing, 70(3), 90-103. doi: 10.1509/jmkg.70.3.90 
Jayachandran, S., Sharma, S., Kaufman, P., \& Raman, P. (2005). The role of relational information processes and technology use in customer relationship management. Journal of Marketing, 69(4), 177-192. doi: 10.1509/jmkg.2005.69.4.177

Jones, E., Brown, S. P., Zoltners, A. A., \& Weitz, B. A. (2005). The changing environment of selling and sales management. Journal of Personal Selling \& Sales Management, 25(2), 105-111.

Krackhardt, D. (1988). Predicting with networks: nonparametric multiple regression analysis of dyadic data. Social Networks, 10(4), 359-381. doi: 10.1016/0378-8733(88)90004-4

Krackhardt, D. (1990). Assessing the political landscape: structure, cognition, and power in organizations. Administrative Science Quarterly, 35(2), 342-69.

Krackhardt, D., \& Stern, R. (1988). Informal networks and organizational crises: an experimental simulation. Social Psychology Quarterly, 51(2), 123-140. doi: 10.2307/2786835

Lazega, E., \& Pattison, P. E. (1999). Multiplexity, generalized exchange and cooperation in organizations: a case study. Social Networks, 21(1), 67-90. doi: 10.1016/S0378-8733(99)00002-7

Lin, N. (1988). Social resources and social mobility: a structural theory of status attainment. In R. Breiger (Ed.), Social mobility and social structure (pp. 247-271). Cambridge: Cambridge University Press.

Moon, M., \& Armstrong, G. (1994). Selling teams: a conceptual framework and research agenda. Journal of Personal Selling and Sales Management, 14(1), 17-30.

Moran, P. (2005). Structural vs. relational embeddedness: social capital and managerial performance. Strategic Management Journal, 26(12), 1129-1151. doi: 10.1002/smj.486

Palmatier, R. W., Dant, R. P., Grewal, D., \& Evans, K. R. (2006). Factors influencing the effectiveness of relationship marketing: a meta-analysis. Journal of Marketing, 70(4), 136-153. doi: $10.1509 / j m k g .70 .4 .136$

Plouffe, C. R., \& Barclay, D. W. (2007). Salesperson navigation: the intraorganizational dimension of the sales role. Industrial Marketing Management, 36(4), 528-539. doi: 10.1016/j.indmarman.2006.02.002

Podolny, J. M., \& Baron, J. N. (1997). Relationships and resources: social networks and mobility in the workplace. American Sociological Review, 62(5), 673-693.doi: 10.2307/2657354

Price, L. L., \& Arnould, E. J. (1999). Commercial friendships: service provider-client relationships in context. The Journal of Marketing, 63(4), 38-56. doi: 10.2307/1251973

Rodan, S., \& Galunic, C. (2004). More than network structure: how knowledge heterogeneity influences managerial performance and innovativeness. Strategic Management Journal, 25(6), 541-562. doi: 10.1002/smj.398

Seevers, M., Skinner, S., \& Kelley, S. (2007). A social network perspective on sales force ethics. Journal of Personal Selling \& Sales Management, 27(4), 341-353.

Stern, R. N. (1979). The development of an interorganizational control network: the case of intercollegiate athletics. Administrative Science Quarterly, 24(2), 242-266.

Steward, M. D., Walker, B. A., Hutt, M. D., \& Kumar, A. (2010). The coordination strategies of highperforming salespeople: internal working relationships that drive success. Journal of the Academy of Marketing Science, 38(5), 550-556. doi: 10.1007/s11747-009-0170-0 
Sujan, H., Sujan, M., \& Bettman, J. (1988). Knowledge structure differences between more effective and less effective salespeople. Journal of Marketing Research, 25(1), 81-86. doi: $10.2307 / 3172927$

Swaminathan, V., \& Moorman, C. (2009). Marketing alliance, firm networks, and firm value creation. Journal of Marketing, 73(5), 52-69. doi: 10.1509/jmkg.73.5.52

Szymanski, D. M., \& Churchill, G. A. (1990). Client evaluation cues: a comparison of successful and unsuccessful salespeople. Journal of Marketing Research, 27(2), 163-174. doi: $10.2307 / 3172843$

Tuli, K. R., Bharadwaj, S. G., \& Kohli, A. K. (2010). Ties that bind: the impact of multiple types of ties with a customer on sales growth and sales volatility. Journal of Marketing Research, 47(1), 36-50. doi: $10.1509 / \mathrm{jmkr} .47 .1 .36$

Uzzi, B. (1997). Social structure and competition in interfirm networks: the paradox of embeddedness. Administrative Science Quarterly, 42(1), 35-67. doi: 10.2307/2393808

Üstüner, T., \& Godes, D. (2006). Better sales networks. Harvard Business Review, 84(7/8), 102-112.

Van Den Bulte, C., \& Wuyts, S. (2007). Social networks in marketing. Cambridge, MA: Marketing Science Institute.

Watts, D. (2004). Six degrees: the science of a connected age. New York: Norton \& Co.

Weitz, B. A., \& Bradford, K. D. (1999). Personal selling and sales management: a relationship marketing perspective. Journal of the Academy of Marketing Science, 27(2), 241-254. doi: 10.1177/0092070399272008

Workman, J. P., Jr., Homburg, C., \& Jensen, O. (2003). Intraorganizational determinants of key account management effectiveness. Journal of the Academy of Marketing Science, 31(1), 3-21. doi: $10.1177 / 0092070302238599$ 